\title{
Climate adaptation, institutional change, and sustainable livelihoods of herder communities in northern Tibet
}

\author{
Jun Wang ${ }^{1}$, Yang Wang ${ }^{2}$, Shuangcheng Li ${ }^{3}$ and Dahe Qin ${ }^{2}$
}

\begin{abstract}
The Tibetan grassland social-ecological systems are widely held to be highly vulnerable to climate change. We aim to investigate livelihood adaptation strategies of herder households and the types of local institutions that shaped those adaptation strategies. We examined the barriers and opportunities for strengthening adaptive capacity of local herder communities. We designed and implemented a household survey in the herder communities of northern Tibet. The survey results showed that migratory grazing has become less feasible. Storage, diversification, and market exchange have become the dominant adaptation strategies. The adaptation strategies of local herders have been reshaped by local institutional change. Local governmental and market institutions played the dominant roles in reshaping climate adaptation strategies. Although the present livelihood adaption strategies related to sedentary grazing have improved productivity and profitability of the herding livelihood, they have led to continuous deterioration of pastures. The local grazing system has become more and more dependent on artificial feeding and inputs from outside the grazing system. Purchasing forage has become one of the dominant adaptation strategies of local herder households. Multilevel regression modeling of this adaptation behavior showed that explanatory variables related to climate variability, household capital, and local institutional arrangements had statistically significant relationships with the adoption of this adaptation strategy. The results implies that building household capital and promoting the coordination among local governmental, market, and communal institutions are critical for strengthening adaptive capacity of the Tibetan herder communities.
\end{abstract}

Key Words: climate adaptation; herder communities; institutional change; sustainable livelihoods; Tibetan Plateau

\section{INTRODUCTION}

Grasslands are the dominant ecosystem type and account for over $70 \%$ of the total land area of the Tibetan Plateau, i.e., $2.57 \times 10^{6}$ $\mathrm{km}^{2}$. The highly variable climate is also a typical feature there, and it creates extremely harsh conditions for livestock grazing. The cold temperature and frequent snowstorms in winter and spring remain a permanent threat to herder communities. Snowstorms are the most destructive climate hazards, and they can lead to high livestock mortality rate (Gao and Qiu 2011, Wang et al. 2013a). Snowstorms, when combined with other environmental and/or socioeconomic stressors, can have disastrous impacts on livelihood sustainability of herders. Intergovernmental Panel on Climate Change projections of climate change show that in the next 20 years (2016-2035), winter precipitation in most parts of the Tibetan plateau will increase about 10\% compared with 1986-2005 (Van Oldenborgh et al. 2013). This implies that snowstorms may increase in frequency and intensity on the Tibetan Plateau. Therefore, the livelihoods of herders will face more challenges from climate change. In recent decades, pasture degradation has been a serious problem on the Tibetan Plateau (Yan et al. 2011, Cao et al. 2013). The impacts of climate variability and change and pasture degradation are closely linked, and together they have threatened livelihood sustainability of the Tibetan herder communities.

In climate change research, vulnerability is defined as a function of exposure to external perturbations, sensitivity to these perturbations, and degree of adaptive capacity and resilience (Adger 2006, Gallopín 2006, Smit and Wandel 2006, Maru et al. 2014). Resilience is the capacity of an open system to absorb disturbance and reorganize while undergoing change so as to retain the essential structure, function, and feedbacks (Walker et al. 2004). Adaptation is a process of deliberate change in response to environmental, economical, or institutional changes that affect livelihood sustainability of communities (Adger et al. 2005). The aim of social adaptation is to reduce vulnerability and increase resilience to perturbations from various stressors (Young 2010). Formal and informal institutions that govern human behaviors and shape how individuals and organizations interact are important for shaping climate adaptation (Adger 2000, Lo 2013, Raymond and Robinson 2013, Chen et al. 2014). Institutions that are adaptive, flexible, responsive, multilevel, and diverse can promote resilience of social-ecological systems (Adger 2000). Adaptation to climate change happens locally, and local institutions play a critical role in shaping climate adaptation (Agrawal 2010). Local adaptation to climate variability and change is usually influenced by the broader institutional, economic, and social contexts (Fernández-Giménez et al. 2012).

Over the past decades, rural institutions have changed dramatically on the Tibetan Plateau (Long et al. 2011, Goldstein 2012). Before the 1950s, herder communities employed seasonal migrations and rotational grazing to adjust to the seasonal and interannual climate variability. They had social norms and rules of collective action that made seasonal migrations work. When climate hazards happened, herders could migrate to pastures owned by other tribes by negotiation. Migratory grazing had the advantage of using the heterogeneous and vast geographic space to adapt to the highly variable climate. In the collective economy period, i.e., from the 1960 s to the 1980 s, pastures and livestock were owned by collectives. Although mobile grazing was still the dominant way to manage livestock, the frequency and distance

\footnotetext{
${ }^{1}$ Peking University Shenzhen Graduate School, Key Laboratory for Human and Environmental Science and Technology, Shenzhen, China, ${ }^{2}$ National Climate Center, China Meteorological Administration, Beijing, China, ${ }^{3}$ College of Urban and Environmental Sciences, Peking University, Beijing, China
} 
of migrations had decreased in this period. Pasture reclamation had caused serious land degradation in some parts of the Tibetan plateau. In the middle 1980s, the Household Production Responsibility System was introduced from the agricultural area of China. Livestock and pastures were mostly allocated to individual herder households. This institutional arrangement has made migratory grazing less feasible (Wu and Yan 2002, Kreutzmann 2011). Since the 1990s, a range of governmental development programs have been implemented in the pastoral areas to alleviate poverty and strengthen adaptive capacity of herder communities to climate variability (Waldron et al. 2010). One typical governmental program involves providing subsidies for local herders to build permanent settlements and winter shelters, fences around pastures, and artificial pastures. Migratory grazing was finally sedentarized in this period.

The Tibetan herder communities have dealt with the highly variable climate and winter snowstorms for thousands of years. Historically, the Tibetan herders developed a range of sophisticated strategies to live with the highly variable climate, such as migratory grazing over time and geographic space, flexibility in migration patterns and underlying social norms (e.g., reciprocity and trust), making use of diverse habitats (e.g., seasonal pastures) and plant species, and exchanging livestock products and items necessary for daily living through local markets. These adaptation strategies helped them to minimize loss in climate hazards and to make optimal use of grassland resources. The Tibetan herders have shown great capacity to deal with climate variability by using their knowledge about local climate patterns, grassland ecology, and livestock management (Goldstein and Beall 1991, Klein et al. 2011, Fu et al. 2012). Livestock grazing is expected to continue to play a critical role in the livelihoods of the Tibetan herder communities. In the context of climate change, herder communities on the Tibetan Plateau will face more climate risks. To make the Tibetan grassland social-ecological systems more resilient, herders must be able to rapidly respond to these changes. To improve adaptive capacity of herder communities, governments need to strengthen and take advantage of already existing adaptation strategies. Therefore, investigating historical livelihood adaptation strategies and associated local institutional facilitators is critical for this purpose.

Several studies have analyzed social vulnerability of the Tibetan herder communities to climate variability and change (Wu and Yan 2002, Fu et al. 2012, Wang et al. 2014). However, more in-depth studies of climate adaptation and the constraints and facilitators of adaptation behaviors at the household-level are still in need. How to alleviate the negative impact of climate change, develop effective response mechanisms, and strengthen adaptive capacity of herder communities is an interesting and significant question. The primary objective of this study is to investigate the major livelihood adaptation strategies of the Tibetan herder households and the types of local institutions that facilitated those adaptation strategies, and we also tried to examine the barriers and opportunities for strengthening adaptive capacity of the Tibetan herder communities. To achieve the objective, we conducted empirical studies in the herder communities of Nagqu County, northern Tibet. Specifically, we focused on the following questions: (1) What were the major livelihood adaptation strategies adopted by the herder households in northern Tibet over the past decade? (2) How did local institutions affect the livelihood adaptation strategies of the Tibetan herder households? (3) What were the determinants of the variations in livelihood adaptation behaviors of the Tibetan herder households?

\section{CONCEPTUAL FRAMEWORK}

The adaptation, institutions, and livelihoods framework

We adopted the adaptation, institutions, and livelihood (AIL) framework developed by Agrawal and Perrin (2009) to analyze climate adaptation, local institutions, and livelihoods of herder communities on the Tibetan Plateau. Social adaptation to climate variability and change is place-based and context-specific, so we modified the AIL framework to accommodate the biophysical and social-institutional contexts of the Tibetan grassland socialecological systems (Fig. 1). In the analytical framework, local institutions were assigned into three types: local public/ governmental institutions, local civic/communal institutions, and local private/market institutions. Agrawal (2010) argued that the three types of local institutions are interlinked, and they can influence climate adaptation of local communities in three important ways: (1) they shape the impact of climate change on rural communities; (2) they shape the ways that communities respond to climate change by different incentive structures; and (3) they are the intermediaries for external interventions and support to local climate adaptation. In addition, Agrawal and Perrin (2009) identified five major livelihood adaptation strategies in the context of policy and climate variations in the semiarid pastoral regions: mobility, storage, livelihood diversification, communal pooling, and market exchange. Mobility used to be the most common adaptation strategy in pastoral areas, and it can pool risks across space. The storage of forage, water, and food can pool climate risks over time. Livelihood diversification reduces climate risks across various assets owned by local households or collectives, and it includes diversification in consumption structures and employment opportunities. Communal pooling spreads risks across people in local communities, and it usually involves sharing labor, assets, income, and resources. Market exchange is an important strategy when communities have accessibility to markets. Depending on the variations in local biophysical, socioeconomic, and institutional contexts, households may adopt different combinations of the five livelihood adaptation strategies.

Fig. 1. The adaptation, institutions, and livelihoods (AIL) framework for analyzing climate adaptation of herder communities on the Tibetan Plateau. The framework was modified from Agrawal and Perrin (2009).

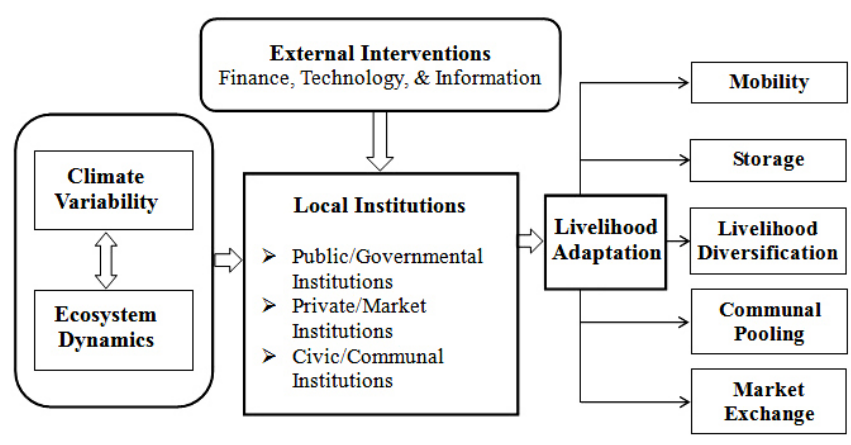




\section{The framework for analyzing livelihood adaptation behaviors} The vulnerability of rural communities to climate change is a function of complex interactions between biophysical, socioeconomic, and institutional factors. The adoption of certain adaptation strategies depends on the characteristics of climate risks, institutional contexts, market accessibility, and household endowments. We built a conceptual framework to analyze livelihood adaptation behaviors of the Tibetan herders (Fig. 2). First, the level of climate risks affects the number and type of livelihood adaptation strategies adopted by herders. Second, adaptation always happens under certain institutional arrangements. For example, market exchange works only if property rights are secured and accessibility to markets is possible. Third, adaptation also depends on the endowments of household capital. Rich households with more household capital usually have more livelihood choices than poor households. In the study area, household human capital includes number of available laborers, i.e., people who were capable of working, years of grazing experience, and years of school education; material capital includes various kinds of household assets, such as living and grazing facilities and the number of livestock owned by the household; natural capital includes pasture area and grassland productivity; financial capital includes annual income from livestock grazing and off-pasture work; and social capital includes social connections, e.g., neighbors, friends, relatives, that herders can rely on when climate hazards happen. Social networks can promote herders to share various kinds of resources, e.g., labor and pastures, in times of scarcity. Overall, climate risks, institutional contexts, market accessibility, and the endowments of household capital collectively affect livelihood adaptation behaviors of herder households, and constraints in any of these factors can cause maladaptation to climate change.

Fig. 2. The framework for analyzing livelihood adaptation behaviors of the Tibetan herder households.

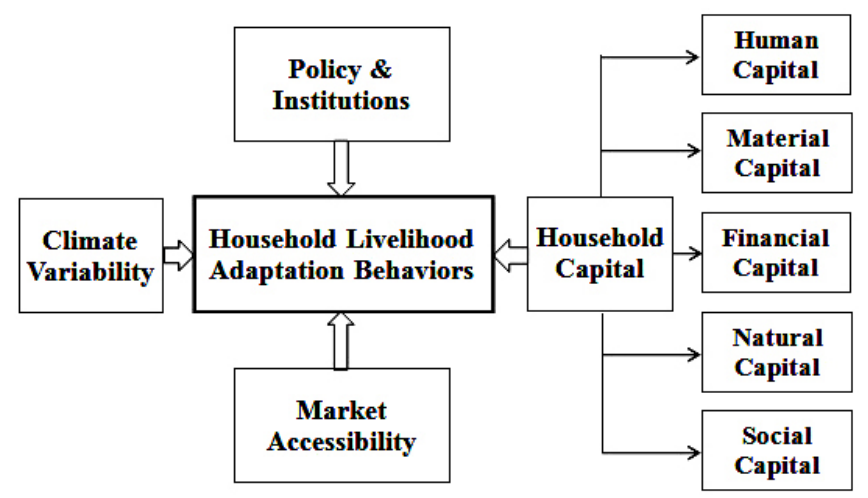

\section{MATERIALS AND METHODS}

\section{Study area and household survey}

We conducted field studies in Nagqu County, a remote area of northern Tibet (Fig. 3). Based on the local census data of the year 2011, this county has 12 towns and 156 villages with the total population of 91,859 . About $90 \%$ of the total land area in this county $\left(16,200 \mathrm{~km}^{2}\right)$ is covered by alpine grasslands and shrubs, and the mean elevation is over $4500 \mathrm{~m}$. The study area is characterized by long and harsh winters and cool and short summers. The vegetation growing season there is from June to August. The alpine grasslands supply forage for an estimated 900,000 head of livestock, including 400,000 head of large livestock (mainly yak and horse), and 500,000 head of sheep and goats. The livelihood source of herder households is mainly from livestock production. About $90 \%$ of annual GDP in this country is from livestock production. According to climate records, annual mean temperature has been increasing since the early 1960s. Annual total precipitation has high interannual variability, and snowstorms happen frequently in winter and spring. Between 1991 and 2010, the accumulated snowfalls in the years 1991, 1997, $1998,2000,2005$, and 2009 were more than $20 \%$ of the 30 -year long annual average. Livestock population was significantly affected by climate hazards, especially by snowstorms (Fig. 4). Given the highly variable climate, it is interesting and meaningful to assess how local herder communities respond to climate variability and change in Nagqu County.

Fig. 3. The study area and the surveyed households in Nagqu County, Northern Tibet.

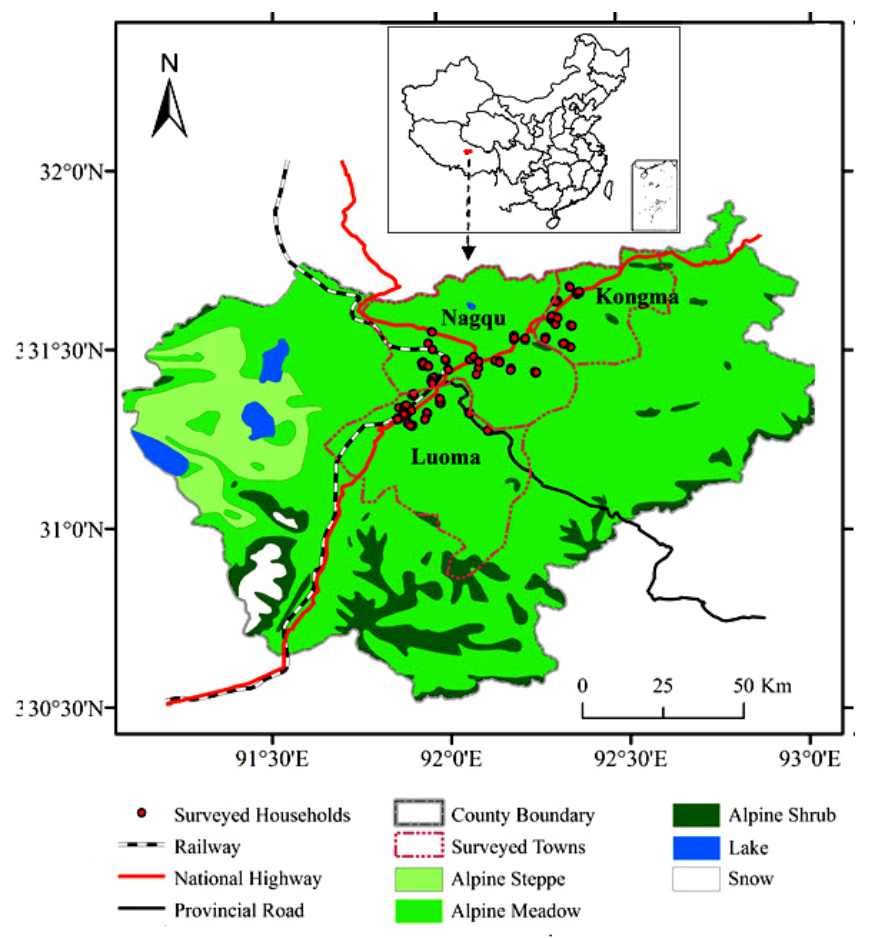

We designed a household survey to collect data related to livelihood adaptation strategies of the herder households in northern Tibet. The survey questionnaire was designed according to the adaptation, institutions, and livelihoods (AIL) framework. Livelihood adaptation strategies were categorized into five types: mobility, storage, communal pooling, livelihood diversification, and market exchange. Local institutions were assigned into three types: governmental, communal, and market institutions. The survey included five sections: (1) socioeconomic and demographic information, livestock population, livestock management 
strategy, pasture-use strategy and forage productivity, household income and expenditure, and living and grazing facilities; (2) memories of climate hazards and perceptions of climate change over the past decade and their impacts on livestock management behaviors; (3) memories of local policy and institutional change over the past decade and recently emerged communal institutions; (4) memories of fluctuations in prices of livestock products over the past decade; and (5) livelihood adaptation strategies over the past decade and associated institutional facilitators. We preselected 42 livelihood adaptation strategies based on the preinterviews with local herders, governmental officials, and grassland experts. The questions were pretested and revised iteratively based on the interviews with herder households.

Fig. 4. The time series of livestock population (A) and snow depth (B) in Nagqu County (1981-2011).
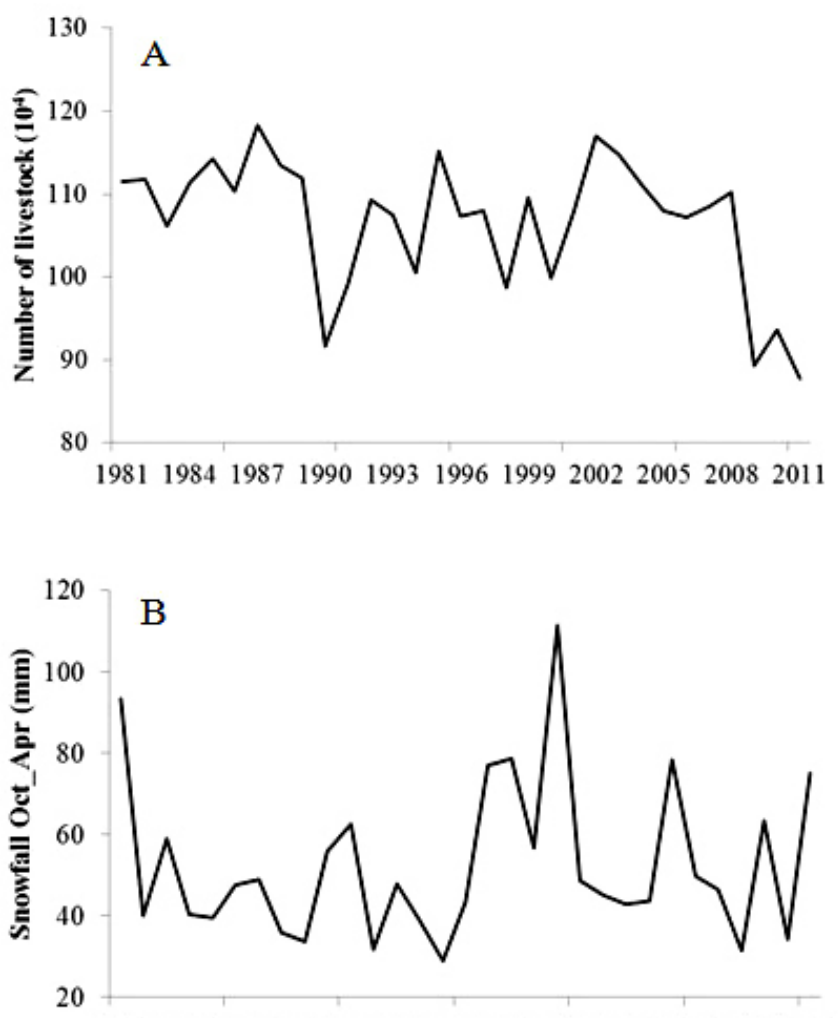

19811984198719901993199619992002200520082011

The household survey was implemented to sample herder households from a variety of biophysical and socioeconomic settings. This was intended to cover a wide range of livelihood adaptation strategies of herder households in the study area. We used a stratified random sampling method for selecting villages and households to be surveyed. First, villages in Nagqu County were stratified by distance to major roads, distance to town centers, densities of human and livestock population, average number of livestock and average pasture area owned by herder households. We randomly selected twenty villages from different categories of villages. The selection of the villages was also based on transportation accessibility. Second, herder households in the selected villages were numbered and selected randomly. We carried out the field work in August, 2013, because heavy winter snowfalls in the study area could make local households less accessible. In each village, we surveyed at least 12 households. In total, we surveyed 296 households distributed in four towns. Moreover, we interviewed local governmental officials and people from the local agricultural and animal husbandry bureau to acquire background information about policies related to livestock grazing and pasture management. Because of the language barrier, all field interviews with local herder households were conducted through local interpreters, and all participants gave their informed consent to be interviewed.

\section{Analyses of household livelihood adaptation strategies}

Investigating the historical livelihood adaptation strategies adopted by the Tibetan herder households has important implications for successful climate adaptation in the future. First, we conducted qualitative analyses of the livelihood adaptations strategies adopted by the respondents. The 42 livelihood adaptation strategies were ranked and categorized into five types according to the AIL framework. For each of the 42 adaptation strategies, we calculated the percentage of the respondents who cited that strategy. Based on the analyses, we identified the dominant livelihood adaptation strategies. Moreover, as discussed above, climate adaptation strategies always emerge within certain institutional contexts. Thus, we paid particular attention to the role of local institutions in climate adaption of herder households and identified the institutional facilitators of those livelihood adaptation strategies.

Second, we conducted analyses of the determinants of adaptation behaviors. Modeling the determinants of livelihood adaptation behaviors is helpful for identifying the constraints of social adaptation. Relaxing those constraints helps to strengthen adaptive capacity of local herder communities. We focused on modeling the adaption behavior of purchasing forage to adapt to climate variability because this was one of the most frequently cited adaptation strategies. With grazing sedentarization and pasture degradation, purchasing and storage of forage has become a critical way to adapt to the highly variable climate (Wang 2011, Yan et al. 2011, Wang et al. 2014). Empirical data related to this strategy was collected at both the household level and village level. We applied multilevel regression models to diagnose the determinants of this adaptation behavior. Multilevel statistical models are designed to deal with nested data. This type of model can be assigned into fixed-effects models and randomeffects models (Gelman and Hill 2007). Fixed-effects models are used when the samples of interest are assumed to not be randomly selected. Random-effects models have the advantage that variance that exists between groups is modeled explicitly. In this study, we applied the random-effects models. Including random effects in the models can also prevent model residuals from being heteroskedastic.

We selected a few variables measured at household and village levels and used them as explanatory variables in the multilevel regression models (Table 1). We used correlation analyses in the variable selection process to minimize the effect of the multicollinearity problem. For household-level variables, the amount of available labor owned by each household was used as the indicator of household human capital. Livestock population measured in sheep forage unit (SFU) and household endowments 
Table 1. The variables measured at household and village levels used for modeling adaptation behaviors.

\begin{tabular}{lll}
\hline \hline Variable & Measurement Item & Measurement Unit \\
\hline Household-level variables & & Unitless \\
Human capital & Number of available labors & Sheep Forage Unit \\
Material capital & Number of livestock & RMB \\
& Living and grazing facilities & RMB \\
Financial capital & Total annual income & Hectare \\
Natural capital & Total area of pastures & Kg/hectare \\
& Forage productivities of pastures & $\%$ \\
Market influence & Percentage of sold livestock last year & Yes/No \\
Pasture use strategies & Pool pastures for communal use in disaster years & Yes/No \\
& Rent pastures from others & Kg \\
Village-level variables & Amount of hay cut from pastures & Unitless \\
Climate variability & & Km \\
Market accessibility & Number of snowstorms happened over the past decade & Yes/No \\
Resource policy & Distance to local town centers & Yes/No \\
& "Grain to Green" program & Yes/No \\
\hline
\end{tabular}

Notes: In the study area, the sheep forage unit for sheep, yak, horse, and goat were set as 1, 5, 6, and 0.8, respectively.

$\mathrm{RMB}=\mathrm{Ren} \mathrm{Min} \mathrm{Bi}$, a unit of currency used in China.

of living and grazing facilities measured in Ren Min Bi (RMB, unit of currency used in China) were used to represent household material capital. The values of SFU varied from 76 to 962 . The annual income was used to represent household financial capital, and this value varied from 1100 to 84,740 RMB. The areas and productivities of summer and winter pastures were used as the indicators of household natural capital. Pasture degradation was more serious in summer pastures than in winter pastures. We used the percentage of sold livestock in the last year to represent the incentive from market demand. The values of this variable varied from $5 \%$ to $68 \%$. We used three variables to represent pasture-use strategies: whether households shared pastures for communal grazing (binary variable), whether households rent pastures from others (binary variable), and the amount of hay-cut from pastures. We did not get high-quality data related to household social capital. Therefore, this variable was not used as an explanatory variable in the multilevel regression models.

For the village-level variables, the number of snow hazards happened over the last decade was used to represent climate variability. We used distance to town centers as the indicator of market accessibility. We selected three variables related to pastureuse policies measured at the village-level: whether the village was involved in the "Grain to Green" program, whether the village has contracted summer pastures to individual households, and whether the village has contracted winter pastures to individual households. All of the above policy variables were binary variables. In the pastoral areas of China, pastures involved in the "Grain to Green" program were abandoned to be natural grasslands (Liu et al. 2008, Waldron et al. 2010). The program that primarily relied on grazing bans, i.e., on seasonal basis and annual basis, has been implemented in 12 of the surveyed villages. All variables, except the binary variables, were rescaled from zero to one by their maximum and minimum values.

To analyze the contributions of each group of the independent variables in explaining the variations in the forage purchasing behaviors, we built five multilevel regression models with different complexity levels. In the models, the variance of the dependent variable was parsed into two parts: household-level variance and village-level variance. The dependent variable in these models was the percentage of income spent on purchasing forage. Model 1 was a random-intercept model without any independent variables, and the village-level effects were included as the random-component of the model.

$$
y_{i, j}=\gamma_{00}+U_{0 j}
$$

In the above Equation, the dependent variable was measured at each household of each village. The first item on the right side of the Equation is the model intercept, and the second item on the right side of the Equation is the random-error term of a specific village. Model 1 was as the baseline model and used to estimate if the village-level variance was statistically significant. Then, different groups of independent variables were included to explore their influences on the total variance.

In Model 2, we included a group of independent variables related to household human capital, material capital, financial capital, and natural capital measured at the household-level.

$$
y_{i, j}=\gamma_{00}+\gamma_{10} x_{1 i, j}+\cdots+\gamma_{q 0} x_{q i, j}+U_{0 j}
$$

The right side of the above Equation includes the fixed-effects of the household-level independent variables and the random-term of a specific village. In Model 3, we included a group of independent variables related to market influence and pastureuse strategies. For Models 2 and 3, those two groups of householdlevel variables were included into the models separately because we aimed to explore whether including the variables of pastureuse strategies can significantly reduce the village-level variance. The increased model predictability was measured by the reduced village-level variance.

Then, we included the village-level independent variables in Models 4 and 5. In Model 4, we included the variable related to 
climate variability, which was measured by the number of snowstorms that occurred in the last decade. We hypothesized that climate variability could significantly affect the forage purchasing behavior. In Model 5, we included the variables related to market accessibility and pasture-use policies.

$$
\begin{gathered}
y_{i, j}=\gamma_{00}+\gamma_{10} x_{1 i, j}+\cdots+\gamma_{q 0} x_{q i, j}+\gamma_{01} z_{1 j} \\
+\cdots+\gamma_{0 r} z_{r j}+U_{0 j}
\end{gathered}
$$

In the above Equation, we included the fixed-effects of villagelevel variables besides the fixed effects of household-level variables. The proportion of variance that was accounted for by the village-level independent variables was calculated by dividing the village-level variance by the total variance. We used the restricted maximum likelihood method for estimating model parameters. The above multilevel regression analyses were conducted using the software package HLM 6.08 (Raudenbush et al. 2012).

\section{RESULTS}

\section{Livelihood adaptation strategies of herder households in northern Tibet}

Migratory grazing, such as seasonal migrations according to climate conditions, used to be the dominant strategy of livestock grazing on the Tibetan Plateau. However, our survey data showed that over $80 \%$ of the respondents cited the adaptation strategy of "migrating less frequently" (Table 2). More than $50 \%$ of the local respondents cited the two adaptation strategies of "stopping migration in the spring" and "only migrating in disaster years." These adaptation strategies were mainly shaped by governmental policies and institutions. As discussed above, under the institutional arrangement of Household Production Responsibility System, most summer and winter pastures were contracted to individual households and fenced for exclusive use. The "Grain to Green" program, which involves grazing bans on a seasonal basis and annual basis, constrained migratory grazing further. "Rotational grazing" has been adopted by the local respondents to improve pasture-use efficiency by dividing summer and winter pastures into smaller grazing parcels. About one-third of the respondents chose to alter time, distance, and locations of migrations in response to environmental change and institutional change. Only a few of the local respondents cited the strategy of "temporarily migrating to urban areas." These respondents reported that they only migrated to urban areas in harsh winters.

Because migratory grazing has become less feasible in the study area, herder households tended to employ other livelihood strategies to adapt to climate variability. To be specific, adaptation strategies belonging to the category of storage generally had the highest citation frequencies in the study sites (Table 2). Storage was used in response to heavy snowstorms, winter cold, and the shortage of forage during winter and spring. "Building permanent houses" was the most frequently cited climate adaptation strategy by the respondents. "Planning artificial grasses and grains," "building new or improving livestock shelters," "stall-feeding more livestock," and "improving the storage of forage" were frequently cited adaptation strategies by the respondents. For example, in the field sites, herder households began to cultivate forage near their settlements to feed livestock. The artificial grasses and grains were planted in spring and harvested at the end of autumn and reserved for winter snowstorms. Forage storage has been improved in the study sites. Forage is now stored in larger and warmer sheds made of mud and wood. Most of the above adaptation strategies were facilitated by governmental institutions. The national government of China has been providing subsidies for local herders to build permanent houses and winter shelters and to stall-feed animals. Market demand has created incentives for herders to increase livestock population. Because of grazing restrictions, increasing the amount of hay cut from pastures was also a popular adaptation strategy. In addition, some of the respondents have changed their food structure by eating less meat and more rice and flour to reduce daily expense.

Communal pooling was one of the frequently cited livelihood adaptation strategies by the respondents. Sharing of labor, pastures, and forage when climate hazards happened were popular. About two-thirds of the respondents cited these three adaptation strategies. In some of the surveyed villages, herders had shared their contracted pastures for communal use when climate hazards happened. Moreover, herding labor and knowledge were shared widely within the surveyed communities. For example, collective hay cutting and hay transporting can benefit from sharing of labor among herders. These adaptation strategies were mainly facilitated by local communal institutions, such as reciprocity and trust. The communal institutions were critical for climate adaptation in the remote Tibetan pastoral areas where local markets and economies were less developed. New communal institutions and organizations, such as livestock disease prevention organizations and livestock production cooperatives, have emerged. The development of local livestock production cooperatives, i.e., producing, processing, and selling livestock products by local collectives, was facilitated by governmental and market institutions. Livestock production cooperatives were mostly organized by local governmental officials, and the national and local governments have been providing subsidies, technology, information, and various kinds of help for herders to organize such livestock production cooperatives for the purpose of improving livestock production efficiency and alleviating rural poverty. The local livestock production cooperatives have become promising for herder communities to adapt to climate change and pasture degradation in the context of rapidly developing market economy.

Subsistence-based livelihood diversification used to be a critical strategy of herder communities to live with the harsh biophysical environment on the Tibetan Plateau. Livelihood diversification strategies cited by the respondents included both subsistenceoriented diversifications and off-pasture income sources. "Taking loans from governments and/or banks" and "changing herd composition" were the two mostly cited adaptation strategies in this category (Table 2). These two strategies were mainly facilitated by governmental and market institutions. The national government of China has been providing low-interest and nointerest loans to the Tibetan herders to support local socioeconomic development and alleviate poverty. Facilitated by governmental leadership and subsides and market incentives, some households have changed their herd compositions by feeding more yaks and less sheep and horses, and bought new animal species to increase household income. Moreover, national and local socioeconomic development created more opportunities for herders to find off-pasture jobs, such as temporary work in local industries and home-based livestock business. Collecting 
Table 2. Livelihood adaptation strategies of herders and institutional facilitators in the surveyed villages.

\begin{tabular}{|c|c|c|c|c|}
\hline Adaptation type & Livelihood adaptation strategies & Percentage $^{\dagger}$ & $\operatorname{Rank}^{\star}$ & Institutions $^{\S}$ \\
\hline \multirow[t]{10}{*}{ Mobility } & Alter the beginning of migratory grazing & 41.67 & 23 & $\mathrm{C}$ \\
\hline & Alter the end dates of migratory grazing & 27.56 & 31 & $\mathrm{C}$ \\
\hline & Alter the duration at summer pastures & 32.05 & 29 & $\mathrm{C}$ \\
\hline & Alter the distance of migratory grazing & 32.69 & 28 & $\mathrm{C}$ \\
\hline & Migrate less frequently & 80.77 & 4 & $\mathrm{G}$ \\
\hline & Stop migratory grazing in spring & 58.33 & 16 & $\mathrm{G}$ \\
\hline & Only migrate in disaster years & 51.48 & 20 & $\mathrm{G} \& \mathrm{C}$ \\
\hline & Start rotational grazing & 26.72 & 32 & $\mathrm{G} \& \mathrm{C}$ \\
\hline & Temporarily migrate to other rural areas & 39.74 & 25 & $\mathrm{C}$ \\
\hline & Temporarily move to urban areas & 6.41 & 41 & $\mathrm{C}$ \\
\hline \multirow[t]{7}{*}{ Storage } & Stall-feed more livestock & 69.23 & 8 & $\mathrm{G} \& \mathrm{M}$ \\
\hline & Build permanent houses & 88.46 & 1 & $\mathrm{G} \& \mathrm{C}$ \\
\hline & Build new or improve livestock shelters & 71.15 & 6 & $\mathrm{G} \& \mathrm{C}$ \\
\hline & Increase the amount of hay cutting & 59.62 & 14 & $\mathrm{C}$ \\
\hline & Reduce expense by consuming less & 53.29 & 19 & $\mathrm{C}$ \\
\hline & Improve the storage of forage & 63.46 & 12 & $\mathrm{G} \& \mathrm{C}$ \\
\hline & Plant artificial grasses and grains & 83.33 & 3 & G \\
\hline \multirow[t]{8}{*}{ Common pooling } & Share labors with others in disaster years & 69.87 & 7 & $\mathrm{C}$ \\
\hline & Share pastures with others in disaster years & 66.03 & 11 & $\mathrm{C}$ \\
\hline & Share forage with others in disaster years & 67.95 & 10 & $\mathrm{C}$ \\
\hline & Share weather information with others & 42.31 & 21 & $\mathrm{C} \& \mathrm{G}$ \\
\hline & Dig wells together with others & 7.69 & 40 & $\mathrm{C}$ \\
\hline & Pool pastures for communal use & 15.86 & 35 & $\mathrm{C}$ \\
\hline & Join livestock disease prevention organizations & 71.79 & 5 & G \\
\hline & Join livestock production cooperatives & 17.74 & 34 & $\mathrm{G} \& \mathrm{M}$ \\
\hline \multirow{8}{*}{$\begin{array}{l}\text { Livelihood } \\
\text { diversification }\end{array}$} & Change herd composition & 60.26 & 13 & $\mathrm{G} \& \mathrm{M}$ \\
\hline & Adopt new animal species & 12.54 & 37 & $\mathrm{G} \& \mathrm{M}$ \\
\hline & Collect caterpillar fungus (herb medicine) & 39.74 & 26 & M \\
\hline & Harvest wild plants for food & 18.03 & 33 & $\mathrm{C}$ \\
\hline & Sell handicrafts and traditional paintings & 32.05 & 30 & $\mathrm{C}$ \\
\hline & Increase the time of temporary off-pasture work & 55.64 & 18 & $M \& G$ \\
\hline & Get income from governmental subsidies & 42.31 & 22 & $\mathrm{G}$ \\
\hline & Take loans from governments/banks & 68.59 & 9 & G \& M \\
\hline \multirow[t]{9}{*}{ Market exchange } & Sell more animals after weather disasters & 56.13 & 17 & M \\
\hline & Sell more animals before weather disasters & 41.03 & 24 & $M \& G$ \\
\hline & Buy forage from markets & 83.97 & 2 & M \\
\hline & Rent pastures from others & 13.82 & 36 & $M \& G$ \\
\hline & Sublease pastures to others & 11.24 & 38 & $M \& G$ \\
\hline & Rent livestock from others & 4.49 & 42 & $\mathrm{M} \& \mathrm{C}$ \\
\hline & Exchange caterpillar fungus for pasture use & 8.33 & 39 & $\mathrm{M} \& \mathrm{C}$ \\
\hline & Buy young animals to increase herd size & 58.97 & 15 & M \\
\hline & Buy female animals to increase herd size & 37.18 & 27 & M \\
\hline
\end{tabular}

Notes: G represents governmental institutions. $\mathrm{M}$ represents market institutions. C represents community institutions. The total number of surveyed households was 296.

${ }^{\dagger}$ The percentage of the households cited that livelihood adaptation strategy.

* The order of the percentage values.

$\S$ The types of local institutions that facilitated those livelihood adaptation strategies.

traditional herd medicine, especially caterpillar fungus, was a popular livelihood strategy, and this was driven by market demand for this traditional herb.

The livelihood adaptation strategies related to market exchange were still under development in the study sites. Market accessibility provided incentives and opportunities for strengthening adaptive capacity of local herder communities. "Selling animals before and after climate hazards" and "purchasing young and female animals to increase herd size" were popular climate adaptation strategies (Table 2). Herders usually did not want to sell animals before climate hazards because the more animals they had the more capable they were able to recover livestock population after hazards. Recently, because of the improved winter shelters and forage storage, some herders chose to sell animals before climate hazards. This helped herders to minimize loss caused by climate hazards. With the increase in livestock population and pasture degradation, herders chose to purchase forage to adapt to climate variability. "Purchasing forage" was the second most frequently cited adaptation strategy by the respondents. Moreover, pasture rental market has emerged in the study area, which was mainly led by the local government. 
Table 3. The estimates of multilevel regression models used for identifying the determinants of forage purchasing behaviors.

\begin{tabular}{|c|c|c|c|c|c|c|c|c|c|c|}
\hline \multirow[t]{2}{*}{ Independent variable } & \multicolumn{2}{|c|}{ Model 1} & \multicolumn{2}{|c|}{ Model 2} & \multicolumn{2}{|c|}{ Model 3} & \multicolumn{2}{|c|}{ Model 4} & \multicolumn{2}{|c|}{ Model 5} \\
\hline & Parameters & SE & Parameters & SE & Parameters & SE & Parameters & $\mathrm{SE}$ & Parameters & $\mathrm{SE}$ \\
\hline \multicolumn{11}{|l|}{ Fixed-effects } \\
\hline \multicolumn{11}{|l|}{ Household-level variables } \\
\hline Intercept & $0.197 * * *$ & 0.028 & $0.123 * * *$ & 0.031 & $0.108 * * *$ & 0.030 & $0.059 * * *$ & 0.024 & $0.071 * * *$ & 0.026 \\
\hline Number of available labors & & & -0.043 & 0.037 & -0.035 & 0.031 & -0.033 & 0.028 & -0.018 & 0.024 \\
\hline Number of livestock & & & $0.288^{* * *}$ & 0.095 & $0.262^{* * *}$ & 0.093 & $0.266^{* * *}$ & 0.101 & $0.243^{* * *}$ & 0.080 \\
\hline Living and grazing facilities & & & 0.107 & 0.072 & 0.093 & 0.068 & 0.061 & 0.060 & 0.054 & 0.048 \\
\hline Total annual income & & & $0.391 * * *$ & 0.104 & $0.370^{* * *}$ & 0.097 & $0.331 * * *$ & 0.094 & $0.308^{* * *}$ & 0.075 \\
\hline Total area of pastures & & & $-0.102^{*}$ & 0.060 & $-0.088^{*}$ & 0.051 & $-0.063^{*}$ & 0.034 & $-0.049 *$ & 0.030 \\
\hline Average productivity of pastures & & & $-0.157^{* * *}$ & 0.056 & $-0.113^{* * *}$ & 0.034 & $-0.108 * * *$ & 0.039 & $-0.124 * *$ & 0.032 \\
\hline Percentage of sold livestock & & & & & -0.064 & 0.078 & -0.053 & 0.069 & -0.050 & 0.087 \\
\hline Pool pastures for communal use & & & & & $-0.048 * *$ & 0.030 & $-0.035 * *$ & 0.023 & $-0.031^{*}$ & 0.019 \\
\hline Rent pastures from others & & & & & -0.023 & 0.045 & -0.012 & 0.037 & -0.009 & 0.013 \\
\hline Amount of cut hay from pastures & & & & & -0.062 & 0.051 & -0.077 & 0.046 & -0.062 & 0.038 \\
\hline \multicolumn{11}{|l|}{ Village-level variables } \\
\hline $\begin{array}{l}\text { Snowstorm count in the past } \\
\text { decade }\end{array}$ & & & & & & & $0.308^{* * *}$ & 0.072 & $0.262^{* * *}$ & 0.049 \\
\hline Distance to local town centers & & & & & & & & & 0.025 & 0.027 \\
\hline "Grain to Green" program & & & & & & & & & 0.017 & 0.035 \\
\hline $\begin{array}{l}\text { Lease winter pastures to } \\
\text { individuals }\end{array}$ & & & & & & & & & 0.029 & 0.056 \\
\hline $\begin{array}{l}\text { Lease summer pastures to } \\
\text { individuals }\end{array}$ & & & & & & & & & 0.033 & 0.050 \\
\hline \multicolumn{11}{|l|}{ Random-effects } \\
\hline $\operatorname{var}(\mathrm{U} 0)$ & $0.021^{* * *}$ & & $0.015^{* * *}$ & & $0.011 * * *$ & & $0.006^{* * *}$ & & $0.003 * * *$ & \\
\hline$\rho(\mathrm{U} 0)$ & 0.457 & & 0.316 & & 0.273 & & 0.192 & & 0.179 & \\
\hline
\end{tabular}

Notes: The total number of surveyed households was 296. The number of surveyed villages was 20. SE means standard error. var(U0) is the variance component at the village-level. $\rho(\mathrm{U} 0)$ is the proportion of variance at the village-level to the total variance.

$* \mathrm{p} \leq 0.05 ; * * \mathrm{p} \leq 0.01 ; * * \mathrm{p} \leq 0.001$.

Buying and selling animals from markets and renting and leasing pastures through pasture rental markets decreased livestock mortality and improved pasture-use efficiency. In addition, renting livestock was another strategy to adapt to climate variability. Herders who lost most of their animals in climate hazards could rent animals from others to recover their livestock population. In some of the surveyed villages, herders chose to exchange the right of collecting caterpillar fungus in their pastures with grazing livestock on other herders' pastures.

\section{Determinants of livelihood adaptation behaviors}

The results of the statistical analyses of the determinants of the variations in forage purchasing behaviors showed that including the variables of household capital reduced the village-level variance (Table 3). The results of Model 2 showed that household livestock population and total annual income had significantly positive relationships with the percentage of household income spent on forage purchasing. Based on the values of the coefficients, total annual income had a larger impact on the dependent variable than household livestock population. The total pasture area and average pasture productivity had significantly negative relationships with the dependent variable because herders with large pasture areas and high-productivity pastures usually need to buy less forage than households with limited areas of low-productivity pastures. The values of the coefficients indicated that pasture productivity had a larger impact on the dependent variable than the area of pastures. The significance level of the coefficient of grassland productivity was also higher than the significance level of the area of pastures. The amount of labor and household endowments of living and grazing facilities had insignificant relationships with the dependent variable. The fact that the endowments of household capital caused variations in adaptation behaviors implies that local herders were disproportionally vulnerable to climate change. The adoption of adaptation practices by specific households was more or less likely depending on their endowments of household capital.

In Model 3, we included four variables related to market influence and pasture-use strategies, and only pooling pasture together for communal use had significantly negative relationships with the dependent variable. The variables related to pasture-use strategies had insignificantly negative relationships with the dependent variable. The modeling results imply that herders, who pooled their pastures for communal grazing, reduced their expenditure on forage. Pasture-use groups were the recently emerged production cooperatives after the implementation of the Household Production Responsibility System. In pasture-use groups, herders autonomously share contracted pastures for communal use. This helped to improve pasture-use efficiency, conserve pasture quality, and spread climate risks across space. Pasture rental markets and the amount of hay cut did not play 
important roles in reducing household expenditure on forage. Pasture rental markets were still under development, and only $13.82 \%$ and $11.24 \%$ of the respondents cited renting and leasing pastures as adaptation strategies, respectively (Table 2).

In Models 4 and 5, we included the village-level variables into the multilevel regression models. In Model 4, we only included the frequency of snowstorms, which was used as an indicator of climate variability. The results showed that this variable had a significantly positive relationship with the dependent variable (Table 3). This implies that climate variability was an important determinant of forage purchasing behaviors. The results of Model 5 showed that distance to town centers, which was used as an indicator of market accessibility, did not have significant relationships with the dependent variable. All of the three variables related to local pasture-use policies, i.e., "Grain to Green" program, leasing winter and summer pastures to individual households, had insignificantly positive relationships with the dependent variable. These may be caused by the facts that not all of the surveyed villages were involved in the "Grain to Green" program, and leasing pastures were also distributed disproportionally among the surveyed villages. Overall, by running a series of regression models, we identified that variables related to household capital, climate variability, and pasture-use strategies played important roles in explaining variations in forage purchasing behaviors. The above analytical methodology can also be used to analyze the determinants of other adaptation behaviors, and this can help to identify the constraints of those adaptation behaviors.

\section{DISCUSSION AND CONCLUSIONS}

Climate change on the Tibetan Plateau has been evident over the pasture decades (Van Oldenborgh et al. 2013). Pasture degradation together with climate change has increased livelihood vulnerability of the Tibetan herder communities ( $\mathrm{Wu}$ and Yan 2002, Yan et al. 2011, Fu et al. 2012). The results of our household survey showed that livelihood adaptation strategies of herder households in northern Tibet have changed dramatically over the past decades. Migratory grazing used to be the dominant adaptation strategy to live with the highly variable climate but has become less feasible. With sedentarization and pasture degradation, storage related strategies have become the dominant adaptation strategies. Communal sharing of labor, pastures, and forage was an old and important adaptation strategy and still worked in the study area. New livestock production cooperatives have emerged and become promising for climate adaptation. Previous studies about the livelihood adaptation strategies of herder households in southeastern Tibet also showed the importance of the above four strategies in climate adaptation $(\mathrm{Fu}$ et al. 2012). The recently emerged livestock production cooperatives belong to community-based resource management (CBRM), and more in-depth analyses about the performance of the new institutional arrangement are still needed. The studies about CBRM in other pastoral systems showed that CBRM can work and fail in sustainable governance of pastures under different conditions (Hausner et al. 2012). In addition, market economy has created new opportunities for herders to diversify their livelihood sources. Market exchange as an important livelihood adaptation strategy was still under development in remote northern Tibet.
Over the past decade, local institutional change and the development of a market economy have reshaped livelihood adaptation strategies of the herder households in northern Tibet. Infrastructure construction, e.g., building roads and railways, funded by the national government has increased market accessibility for the Tibetan herders. Promoting accessibility to markets provided opportunities for herders to find new livelihood sources in market economy. The policy interventions to promote market-based strategies and nonpasture related livelihood opportunities have been crucial in strengthening adaptive capacity of local herder communities. With substantial external inputs in the forms of forage, finance, and technology, the adaptive capacity of the Tibetan herder communities have been greatly improved. This can be substantiated by the fact that livestock mortality rate in Nagqu County has significantly decreased over the past decade. The studies about the transitions in the reindeer management in northern Finland from intensive management to extensive management also indicated that intensive management of livestock was important in decreasing livestock mortality in winter snowstorms (Helle and Jaakkola 2008). However, sedentary grazing can increase the cost of livestock production because herders have to purchase forage to provide supplementary fodder. Therefore, governmental policies about grazing sedentarization and market incentives for increasing livestock production can undermine adaptive capacity of the Tibetan herder communities. From this perspective, institutional change has made the Tibetan grassland socialecological systems less resilient to climate variability and change. The studies in the Saami pastoral ecosystems also showed that policy interventions for modernizing traditional pastoral systems decreased resilience of the local pastoral systems to climate variability (Hausner et al. 2011). Similar changes also happened in the pastoral systems of the Inner Mongolia Autonomous Region, China (Wang et al. 2013b).

We developed a framework to analyze livelihood adaptation behaviors of herders, and we investigated the determinants of one of the most frequently cited adaptation strategies, i.e., purchasing forage, by running a series of multilevel regression models. The results showed that variables related to climate variability, household capital, and local pasture-use institutions were important in influencing forage purchasing behaviors. This implies that building household capital and designing suitable institutional arrangements are important for strengthening adaptive capacity of the Tibetan herder communities in the context of climate change. Besides climate change, pasture degradation is also one important environmental change that has driven the Tibetan herder households to change their livelihood strategies (Yan et al. 2011). The empirical studies in eastern Tibet by Yan et al. (2011) showed that in the three counties they surveyed, the proportions of supplementary forage for livestock were all over $50 \%$. They claimed that this was mainly caused by pasture degradation and sedentary grazing. The results of our regression modeling showed that pasture productivity had significantly negative relationship with the percent income spent on purchasing forage. The above facts imply that recovering grassland quality is also important for increasing resilience of the Tibetan grassland social-ecological systems to future climate change. 
In conclusion, this study has improved our understanding of livelihood adaptation strategies developed by the herder households in northern Tibet and the important role of local institutions in shaping climate change adaptation. Over the past decades, local institutional change has reshaped livelihood adaptation strategies of local herders. Local governmental and market institutions played the dominant roles in reshaping livelihood adaptation strategies. Local institutions have strengthened and undermined adaptive capacity of local herder communities in different ways. In the study area, livelihood adaptation strategies can be mainly assigned into the present adaptation strategies related to sedentary grazing, which were mainly shaped by local governmental and market institutions, and the traditional adaptation strategies related to migratory grazing, which were mainly shaped by local communal institutions. Although the present livelihood adaption strategies related to sedentary grazing have improved grassland productivity and economic profitability of the herding livelihood, they have led to continuous deterioration of pastures. The local grazing system has become more and more dependent on artificial feeding and inputs coming from outside the grazing system. From the ecological, economic, and social sustainability perspective, although the present adaptation strategies have improved the economic and social sustainability of local herder communities, the ecological sustainability of the study area has been deteriorated. However, although the traditional adaptation strategies related to migratory grazing kept the economic and social sustainability of local herder communities low, they preserved the ecological sustainability of the grazing pastures. Therefore, promoting the coordination among multiple local governmental, market, and communal institutions is critical for facilitating climate change adaptation and improving livelihood sustainability of the Tibetan herder communities.

Responses to this article can be read online at: http://www.ecologyandsociety.org/issues/responses. $\mathrm{php} / 8170$

\section{Acknowledgments:}

This work was conducted with financial support from the State Key Laboratory of Cryospheric Sciences, Cold and Arid Regions Environment and Engineering Research Institute, China (SKLCSOP-2014-10), Laboratory for Climate Studies Open Funds for Young Scholars, China (2015), and National Science Foundation of China (41401215). The authors would like to thank people from the local government of Nagqu County for their generous help with the household surveys.

\section{LITERATURE CITED}

Adger, W. N. 2000. Institutional adaptation to environmental risk under the transition in Vietnam. Annals of the Association of American Geographers 90(4):738-758. http://dx.doi. org/10.1111/0004-5608.00220

Adger, W. N. 2006. Vulnerability. Global Environmental Change 16(3):268-281. http://dx.doi.org/10.1016/j.gloenvcha.2006.02.006
Adger, W. N., N. W. Arnell, and E. L. Tomplins. 2005. Successful adaptation to climate change across scales. Global Environmental Change 15(2):77-86. http://dx.doi.org/10.1016/j.gloenvcha.2004.12.005

Agrawal, A. 2010. Local institutions and adaptation to climate change. Page 173-197 in R. Mearns and A. Norton, editors. Social dimensions of climate change: equity and vulnerability in a warming world. The World Bank, Washington, D.C., USA.

Agrawal, A., and N. Perrin. 2009. Climate adaptation, local institutions and rural livelihoods. Pages 350-367 in W. N. Adger, L. Lorenzoni, K. L. O'Brien, editors. Adapting to climate change: thresholds, values, governance. Cambridge University Press, New York, New York, USA. http://dx.doi.org/10.1017/cbo9780511596667.023

Cao, J., E. T. Yeh, N. M. Holden, Y. Yang, and G. Du. 2013. The effects of enclosures and land-use contracts on rangeland degradation on the Qinghai-Tibetan plateau. Journal of Arid Environments 97:3-8. http://dx.doi.org/10.1016/j.jaridenv.2013.05.002

Chen, H., J. Wang, and J. Huang. 2014. Policy support, social capital, and farmers' adaptation to drought in China. Global Environmental Change 24:193-202. http://dx.doi.org/10.1016/j. gloenvcha.2013.11.010

Fernández-Giménez, M. E., B. Batkhishig, and B. Barbuyan. 2012. Cross-boundary and cross-level dynamics increase vulnerability to severe winter disasters (dzud) in Mongolia. Global Environmental Change 22(4):836-851. http://dx.doi.org/10.1016/ j.gloenvcha.2012.07.001

$\mathrm{Fu}$, Y., R. E. Grumbine, A. Wilkes, Y. Wang, J.-C. Xu, and Y.-P. Yang. 2012. Climate change adaptation among Tibetan pastoralists: challenges in enhancing local adaptation through policy support. Environmental Management 50(4):607-621. http:// dx.doi.org/10.1007/s00267-012-9918-2

Gallopín, G. C. 2006. Linkages between vulnerability, resilience, and adaptive capacity. Global Environmental Change 16 (3):293-303. http://dx.doi.org/10.1016/j.gloenvcha.2006.02.004

Gao, M., and J. Qiu. 2011. Characteristics and distribution law of major natural disasters in Tibetan Plateau. Journal of Arid Land Resources and Environment 25(8):101-106.

Gelman, A., and J. Hill. 2007. Data analysis using regression and multilevellhierarchical models. Cambridge University Press, New York, New York, USA. http://dx.doi.org/10.1017/cbo9780511790942

Goldstein, M. C. 2012. Change and continuity in a nomadic pastoralism community in the Tibet Autonomous Region, 1959-2009. Pages 257-272 in H. Kreutzmann, editor. Pastoral practices in High Asia. Springer, New York, New York, USA. http://dx.doi.org/10.1007/978-94-007-3846-1 14

Goldstein, M., and C. Beall. 1991. Change and continuity in nomadic pastoralism on the Western Tibetan Plateau. Nomadic Peoples 28:105-122.

Hausner, V. H., P. Fauchald, and J.-L. Jernsletten. 2012. Community-based management: Under what conditions do Sámi pastoralists manage pastures sustainability? PLOS ONE 7(12): e51187. http://dx.doi.org/10.1371/journal.pone.0051187

Hausner, V. H., P. Fauchald, T. Tveraa, E. Pedersen, J. Jernslettern, B. Ulvevadet, R. A. Ims, N. G. Yoccoz, and K. A. 
Bråthen. 2011. The ghost of development past: the impact of economic security policies on Saami pastoral ecosystems. Ecology and Society 16(3):4. http://dx.doi.org/10.5751/ES-04193-160304

Heller, T. P., and L. M. Jaakkola. 2008. Transitions in herd management of semi-domesticated reindeer in northern Finland. Annales Zoologici Fennici 45(2):81-101. http://dx.doi. org/10.5735/086.045.0201

Klein, J. A., E. Yeh, J. Bump, Y. Nyima, and K. Hopping. 2011. Coordinating environmental protection and climate change adaptation policy in resource-dependent communities: a case study from the Tibetan Plateau. Pages 423-438 in J. Ford and L. Berrang-Ford, editors. Climate change adaptation in developed nations: from theory to practice. Springer, New York, New York, USA. http://dx.doi.org/10.1007/978-94-007-0567-8 31

Kreutzmann, H. 2011. Pastoral practices on the move-recent transformations in mountain pastoralism on the Tibetan Plateau. Pages 200-224 in H. Kreutzmann, H. Yang, and J. Richter, editors. Pastoralism and rangeland management on the Tibetan Plateau in the context of climate and global change. Federal Ministry for Economic Cooperation and Development, Berlin, Germany.

Liu, J., S. Li, Z. Ouyang, C. Tam, and X. Chen. 2008. Ecological and socioeconomic effects of China's policies for ecosystem services. Proceedings of the National Academy of Sciences 105 (28):9477-9482. http://dx.doi.org/10.1073/pnas.0706436105

Lo, A. Y. 2013. The role of social norms in climate adaptation: mediating risk perception and flood insurance purchase. Global Environmental Change 23(3):1249-1257. http://dx.doi.org/10.1016/ j.gloenvcha.2013.07.019

Long, R., X. Liu, G. Cui, and W. Zhang. 2011. Socioeconomic changes in pastoral systems on the Tibetan Plateau. Pages 239-255 in H. Kreutzmann, H. Yang, and J. Richter, editors. Pastoralism and rangeland management on the Tibetan Plateau in the context of climate and global change. Federal Ministry for Economic Cooperation and Development, Berlin, Germany.

Maru, Y. T., M. Stafford Smith, A. Sparrow, P. F. Pinho, and O. P. Dube. 2014. A linked vulnerability and resilience framework for adaptation pathways in remote disadvantaged communities. Global Environmental Change 28:337-350 http://dx.doi. org/10.1016/j.gloenvcha.2013.12.007

Raudenbush, S., A. Bryk, and K. Congdon. 2012. HLM 6. Hierarchical linear and non-linear modeling. Scientific Software International, Skokie, Illinois, USA.

Raymond, C. M., and G. M. Robinson. 2013. Factors affecting rural landholder's adaptation to climate change: insights from formal institutions and communities of practice. Global Environmental Change 23(1):103-114. http://dx.doi.org/10.1016/ j.gloenvcha.2012.11.004

Smit, B., and J. Wandel. 2006. Adaptation, adaptive capacity and vulnerability. Global Environmental Change 16(3):282-292. http:// dx.doi.org/10.1016/j.gloenvcha.2006.03.008

Van Oldenborgh, G., M. Collins, J. Arblaster, J. Christensen, J. Marotzke, S. Power, M. Rummukainen, and T. Zhou. 2013. Annex I: Atlas of global and regional climate projections. Pages 1311-1394 in T. Stocker, D. Qin, G. Plattner, M. Tignor, S. Allen,
J. Boschung, A. Nauels, Y. Xia. V. Bex, and P. Midgley, editors. Climate change 2013: the physical science basis. Contribution of Working Group I to the Fifth Assessment Report of the Intergovernmental Panel on Climate Change. Cambridge University Press, New York, New York, USA.

Waldron, S., C. Brown, and J. Longworth. 2010. Grassland degradation and livelihoods in China's western pastoral region: a framework for understanding and refining China's recent policy responses. China Agricultural Economic Review 2(3):298-320. http://dx.doi.org/10.1108/17561371011078435

Walker, B., C. S. Holling, S. R. Carpenter, and A. Kinzig. 2004. Resilience, adaptability and transformability in social-ecological systems. Ecology and Society 9(2):5. [online] URL: http://www. ecologyandsociety.org/vo19/iss2/art5/

Wang, J. 2011. Integrating agricultural and pastoral resources for poverty alleviation and reducing eco-pressure on rangelands. Pages 225-238 in H. Kreutzmann, H. Yang, and J. Richter, editors. Pastoralism and rangeland management on the Tibetan Plateau in the context of climate and global change. Federal Ministry for Economic Cooperation and Development, Berlin, Germany.

Wang, J., D. G. Brown, and A. Agrawal. 2013b. Sustainable governance of the Mongolian grasslands: comparing ecological and social-institutional changes in the context of climate change in Mongolia and Inner Mongolia Autonomous Region, China. Pages 425-446 in J. Chen, S. Wan, G. Henebry, J. Qi, G. Gutman, G. Sun, and M. Kappas, editors. Dryland East Asia: land dynamics amid social and climate change. De Gruyter, Berlin, Germany. http://dx.doi.org/10.1515/9783110287912.425

Wang, W., T. Liang, X. Huang, Q. Feng, H. Xie, X. Liu, M. Chen, and X. Wang. 2013a. Early warning of snow-caused disasters in pastoral areas on the Tibetan Plateau. Natural Hazards and Earth System Sciences 13:1411-1425. http://dx.doi.org/10.5194/ nhess-13-1411-2013

Wang, Y., J. Wang, S. Li, and D. Qin. 2014. Vulnerability of the Tibetan pastoral systems to climate and global change. Ecology and Society 19(4):8. http://dx.doi.org/10.5751/ES-06803-190408

$\mathrm{Wu}$, N., and Z. Yan. 2002. Climate variability and social vulnerability on the Tibetan Plateau: dilemmas on the road to pastoral reform. Erdkunde 56(1):2-14. http://dx.doi.org/10.3112/ erdkunde.2002.01.01

Yan, J., Y. Wu, and Y. Zhang. 2011. Adaptation strategies to pasture degradation: gap between government and local nomads in the eastern Tibetan Plateau. Journal of Geographical Sciences 21(6):1112-1122. http://dx.doi.org/10.1007/s11442-011-0904-z

Young, O. R. 2010. Institutional dynamics: resilience, vulnerability and adaptation in environmental and resource regimes. Global Environmental Change 20(3):378-385. http://dx. doi.org/10.1016/j.gloenvcha.2009.10.001 